\title{
PENGARUH PAKAN ALAMI Chaetoceros spp. TERHADAP PERKEMBANGAN DAN SINTASAN LARVA UDANG WINDU, Penaeus monodon
}

\author{
Samuel Lante ${ }^{\#}$ dan Herlinah \\ Balai Penelitian dan Pengembangan Budidaya Air Payau \\ (Naskah diterima: 30 Januari 2015; Revisi final: 28 Agustus 2015, Disetujui publikasi: 2 September 2015)
}

\begin{abstract}
ABSTRAK
Pakan alami berupa mikroalga merupakan salah satu faktor pendukung dalam keberhasilan usaha pembenihan udang windu, Penaeus monodon. Penelitian ini bertujuan untuk mengetahui jenis pakan alami, Chaetoceros spp., yang dapat meningkatkan pertumbuhan dan sintasan larva udang windu. Penelitian ini menggunakan 15 buah bak fiber berukuran $60 \mathrm{~cm}$ x $40 \mathrm{~cm}$ x $50 \mathrm{~cm}$ dengan volume 120 liter yang disi air sebanyak 100 liter. Kepadatan naupli adalah 90 ekor/liter atau 9.000 ekor/bak dan lima jenis pakan alami Chaetoceros spp. yang diuji yaitu: Chaetoceros simplex, Chaetoceros ceratosporum, Chaetoceros calcitrans, Chaetoceros amami, dan Chaetoceros gracilis. Hasil penelitian menunjukkan bahwa aplikasi kelima jenis pakan alami memberikan laju perkembangan larva yang relatif sama sampai stadia PL-1. Aplikasi Chaetoceros gracilis memberikan sintasan larva udang windu tertinggi yaitu 41,48\% dan dengan Chaetoceros simplex memberikan sintasan larva terendah $(28,02 \%)$. Hasil penelitian ini mengindikasikan bahwa aplikasi Chaetoceros spp. yang berbeda pada pemeliharaan larva berpengaruh terhadap sintasan larva udang windu, namun tidak berpengaruh terhadap laju metamorfosis larva. Aplikasi Chaetoceros gracilis sebagai pakan alami adalah terbaik untuk sintasan larva udang windu.
\end{abstract}

KATA KUNCI: Chaetoceros spp., pertumbuhan, sintasan, udang windu

ABSTRACT: The effect of microalgae Chaetoceros spp. for survival rate and development of larval tiger shrimp, Penaeus monodon. By: Samuel Lante and Herlinah

Microalgae is one of important factor contributing to the success of hatchery production of tiger shrimp, Penaeus monodon. This study aimed to determine the species of live food, Chaetoceros spp. which can stimulate better growth and survival rate of tiger shrimp larvae. This trial used 15 fiber tanks (size $60 \mathrm{~cm} \times 40 \mathrm{~cm} \times 50 \mathrm{~cm}$ ) with 120 liters capacity filled with 100 liters seawater. Stocking density was 90 larvae/liter or 9,000 larvae/tank. Five species of Chaetoceros spp. were used namely: Chaetoceros simplex, Chaetoceros ceratosporum, Chaetoceros calcitrans, Chaetoceros amami, and Chaetoceros gracilis. The results of study showed that application of the five species of Chaetoceros spp. gave the same development rate to PL-1 among the treatments. Chaetoceros gracilis yielded the highest survival rate of tiger shrimp larvae at $41.48 \%$ and the lowest survival rate was observed in larvae fed Chaetoceros simplex (28.02\%). These results indicated that the application of the five Chaetoceros spp. on larvae rearing gave significant different on tiger shrimp larvae survival rate but not significant difference for larvae metamorphosis stage. Application of Chaetoceros gracilis gave the best survival rate of tiger shrimp larvae.

KEYWORDS: Chaetoceros spp., growth, survival rate, tiger shrimp

\section{PENDAHULUAN}

Perkembangan usaha pembenihan di Indonesia dari tahun ke tahun mengalami peningkatan, maka peranan dan ketersediaan pakan alami mikroalga semakin meningkat. Ketersediaan pakan alami yang sesuai seperti: jenis, jumlah, mutu dan kesinambu-

\# Korespondensi: Balai Penelitian dan Pengembangan Budidaya Air Payau. Jl. Makmur Dg. Sitakka No. 129, Maros 90512, Sulawesi Selatan, Indonesia. Tel.: + (0411) 371544; 371545 E-mail: samuellante98@yahoo.co.id ngannya merupakan salah satu faktor penentu keberhasilan pemeliharaan larva krustasea. Renaud et al. (1999) menguraikan bahwa pakan alami terutama mikroalga merupakan sumber protein, karbohidrat, dan lemak. Chaetoceros spp. merupakan salah satu pakan alami yang umum digunakan dalam marikultur karena memiliki kandungan protein yang tinggi dan mudah untuk dicerna (Sektiana, 2008). Mikroalga ini memiliki banyak manfaat antara lain sebagai sumber pakan karena kandungan protein, karbohidrat, dan asam lemaknya yang cukup tinggi untuk pertum- 
buhan beberapa jenis larva udang (Sutomo, 2005). Penggunaan pakan alami pada pembenihan udang sangat besar peranannya, sehingga keberadaan mikroalga memerlukan pengelolaan yang tepat dan cermat. Mikroalga tidak hanya memerankan sebagai sumber pakan, tetapi bersama-sama dengan bakteri mempunyai peranan penting dalam keseimbangan oksigen $\left(\mathrm{O}_{2}\right)$ dan karbondioksida $\left(\mathrm{CO}_{2}\right)$ dalam media kultur. Mikroalga merupakan komponen esensial dalam pakan larva krustasea. Selain esensial sebagai pakan, pasokan mikroalga dapat meningkatkan sintasan larva.

Hasil survai terhadap keragaan penggunaan pakan alami pada pembenihan udang di Jawa Timur menunjukkan hampir $92 \%$ menggunakan pakan alami Skeletonema sp, sedangkan di Bali dan Sulawesi Selatan masing-masing 45\% dan 75\% (Haryanti et al., 1991). Ini menunjukkan bahwa penggunaan diatom jenis Skeletonema sp. relatif besar. Sementara itu, kultur jenis diatom ini tidak selalu mudah dilakukan, baik skala massal maupun laboratorium. Juga sangat tergantung pada cuaca dan ketersediaan sumber spesies ini tidak berada di semua perairan. Oleh karena itu, perlu dipertimbangan untuk memanfaatkan jenis alga uniselluler lainnya yang mempunyai fleksibilitas terhadap perubahan lingkungan dan didukung oleh kandungan nutrisi yang memadai bagi pertumbuhan larva udang. Di antara jenis diatom yang ada dan dapat digunakan sebagai pakan alami udang windu adalah Chaetoceros spp.

Ada beberapa jenis Chaetoceros spp. yang diduga merupakan spesies yang berbeda dan memberikan kualitas nutrisi serta pengaruh yang berbeda terhadap performa larva udang. Chaetoceros spp. sebagai genus terbesar dalam diatom laut dengan jumlah spesies sekitar 400 dan merupakan dasar dari rantai makanan bagi larva udang seperti Penaeus monodon dan P. vannamei (Cahyaningsih, 2009 dalam Rahmadiani \& Aunurohim, 2013). Di antaranya Chaetoceros gracilis sudah digunakan sebagai pakan yang baik bagi $P$. stylirostris dan P. vannamei dari stadia zoea sampai mysis dengan sintasan 84,8\%, (Simon, 1978). Biota jenis ini (C. gracilis) merupakan diatom sentrik yang soliter, organisme uniseluler dengan ukuran mulai dari 0,5 $\mu \mathrm{m}$ hingga $2,0 \mu \mathrm{m}$ (Suantika et al., 2009), serta menghasilkan komponen antibakteri (Setyaningsih et al., 2012). Jenis Chaetoceros calcitrans mengandung poly unsaturated fatty acid (PUFA) sebesar 33,7\% lebih besar, mudah dipelihara, dan memiliki pertumbuhan cepat dibanding jenis lain (Boeing, 2008 dalam Rahmadiani \& Aunurohim, 2013). Oleh karena itu, aplikasi Chaetoceros spp. sebagai pakan alami pada pembenihan udang windu diharapkan dapat meningkatkan pertumbuhan dan sintasan larva. Berdasarkan kondisi tersebut diperlukan kajian untuk mengeva- luasi penggunaan lima jenis Chaetoceros spp. sebagai pakan alami terhadap laju perkembangan larva udang dan sintasannya. Tujuan penelitian ini adalah untuk mengetahui jenis pakan alami Chaetoceros spp. yang dapat memberikan laju perkembangan larva dan sintasan larva udang yang tinggi.

\section{BAHAN DAN METODE}

Penelitian dilaksanakan di Instalasi Pembenihan Udang Windu, Balai Penelitian dan Pengembangan Budidaya Air Payau, Maros. Wadah penelitian menggunakan 15 buah bak dengan kapasitas 120 liter yang diisi air sebanyak 100 liter. Kepadatan hewan uji adalah 90 ekor naupli/liter atau 9.000 ekor naupli/bak. Larva udang dipelihara dengan pemberian pakan alami Chaetoceros spp. Kepadatan awal masing-masing jenis plankton yang diuji adalah $5.000 \mathrm{sel} / \mathrm{mL}$, dan selanjutnya ditingkatkan sesuai pertumbuhan larva. Kepadatan sel plankton dihitung dengan menggunakan haemocytometer setiap hari, untuk menentukan kepadatan pakan alami berikutnya yang disesuaikan dengan perkembangan larva. Lama pemeliharaan larva sampai stadia postlarva-1. Untuk menumbuhkan pakan alami maka digunakan pupuk dengan komposisi (Tabel 1). Sebagai perlakuan adalah pemberian pakan alami jenis Chaetoceros simplex (A), C. ceratosforum (B), C. calcitrans (C), C. amami (D), dan C. gracilis (E). Sedangkan pada stadia zoea-2 akhir ditambahkan pakan buatan mikro-encapsulasi dan pada stadia mysis-2 akhir ditambahkan nauplii Artemia sp. dengan kepadatan 5-10 nauplii/larva. Penelitian didesain dengan rancangan acak lengkap dengan lima perlakuan dan tiga ulangan. Selama penelitian, kepadatan pakan uji dan pergantian air pada bak pemeliharaan larva udang disajikan pada Tabel 2.

Penerimaan larva udang windu terhadap pakan alami Chaetoceros spp. ditentukan dengan menganalisis laju konsumsi alga oleh larva udang windu. Laju konsumsi/kecernaan alga oleh larva udang windu (I)

Tabel 1. Komposisi nutrien untuk kultur massal Chaetoceros spp.

Table 1. Nutrient composition for mass culture of Chaetoceros spp.

\begin{tabular}{lc}
\hline Nutrien (Nutrient) & $\begin{array}{c}\text { Dosis } \\
\text { Dosage (ppm) }\end{array}$ \\
\hline $\mathrm{KNO}_{3}$ & 100 \\
$\mathrm{NaH}_{2} \mathrm{PO}_{4} \cdot 2 \mathrm{H}_{2} \mathrm{O}$ & 10 \\
$\mathrm{FeCl}_{3}$ & 1.3 \\
$\mathrm{EDTA}$ & 10 \\
$\mathrm{NaSiO}_{3}$ & 15 \\
\hline
\end{tabular}

Sumber (Source): Liao \& Lin (1983) 
Tabel 2. Kepadatan Chaetoceros spp, dan pergantian air pada setiap stadia larva

Table 2. Chaetoceros spp. density and water exchange for each stadia of larvae

\begin{tabular}{lcc}
\hline \multicolumn{1}{c}{ Stadia (Stadia) } & $\begin{array}{c}\text { Kepadatan alga }(\mathrm{Sel} / \mathrm{mL}) \\
\text { Algae density }(\text { Cell/mL) }\end{array}$ & $\begin{array}{c}\text { Pergantian air } \\
\text { Water exchange }(\%)\end{array}$ \\
\hline Nauplius / Zoea & 50 & 0 \\
Zoea-1 & 60 & 0 \\
Zoea-2 & 80 & $0-5$ \\
Zoea-3 & 100 & $5-10$ \\
Mysis-1 & 120 & $10-15$ \\
Mysis-2 & 130 & $15-20$ \\
Mysis-3 & 120 & $20-25$ \\
Mysis-3 / PL-1 & 100 & $25-35$ \\
PL-1 & 80 & 850 \\
\hline
\end{tabular}

dihitung dengan mengadopsi persamaan Frost (1972) dalam Band-Schmidt et al. (2008) sebagai berikut:

$$
\begin{gathered}
\mathrm{I}=\{(\mathrm{V} \times \mathrm{g}) / \mathrm{N}\} \times \mathrm{C} \\
\mathrm{g}=\left(\ln \mathrm{C}_{\mathrm{i}}-\ln \mathrm{C}_{\mathrm{f}}\right) /(\mathrm{t}+\mathrm{k})
\end{gathered}
$$

di mana:

$\mathrm{V}=$ Volume sel alga setiap wadah $(\mathrm{mL})$

$\mathrm{g}=$ Koefisien pemangsaan

$\mathrm{N}=$ Jumlah larva udang setiap wadah

$\mathrm{C}=$ Kepadatan sel alga $(\mathrm{sel} / \mathrm{mL})$

$\mathrm{C}_{\mathrm{i}}=$ Kepadatan awal sel alga $(\mathrm{sel} / \mathrm{mL})$

$\mathrm{C}_{\mathrm{f}}=$ Kepadatan akhir sel alga $(\mathrm{sel} / \mathrm{mL})$

$\mathrm{t}=$ Waktu (jam)

$\mathrm{k}=$ Laju pertumbuhan alga per jam

Perkiraan kepadatan larva secara harian dihitung dengan metode pengambilan sampel menggunakan $500 \mathrm{~mL}$ beakerglass sebanyak tiga kali. Pengamatan laju metamorfosis larva dikuantitasikan dengan indeks perkembangan larva (Villegas \& Kanazawa, 1979) sebagai berikut:

$$
\mathrm{L}_{\mathrm{m}}=\frac{\sum \mathrm{A}_{\mathrm{i}} \times \mathrm{t}_{\mathrm{i}}}{\mathrm{n}}
$$

di mana:

$\mathrm{L}_{\mathrm{m}}=$ Laju metamorfosis/perkembangan larva

$A_{i}=$ Jumlah larva pada stadia ke-i dari jumlah contoh yang diamati

$\mathrm{t}_{\mathrm{i}}=$ Nilai absolut larva stadia ke-i (zoea- $1=1$, zoea- $2=$ 2 , zoea- $3=3$, mysis- $1=4$, mysis- $2=5$, mysis- $3=$ 6 , pascalarva- $1=7$

$\mathrm{n}=$ Jumlah contoh yang diamati

Sintasan larva pada setiap perlakuan dengan menggunakan rumus Effendie (1979), sebagai berikut:

$$
S=\frac{N_{t}}{N_{o}} \times 100 \%
$$

di mana:

$\mathrm{S}=$ Sintasan (\%)

$\mathrm{N}_{\mathrm{t}}=$ Jumlah larva yang hidup pada akhir penelitian (ekor)

$\mathrm{N}_{\mathrm{o}}=$ Jumlah larva pada awal penelitian (ekor)

Analisis proksimat alga dilakukan berdasarkan metode AOAC International (1999), yaitu protein kasar ditentukan dengan metode Kjeldahl, lemak kasar dengan metode ekstraksi ether menggunakan soxhlet, kadar abu ditentukan dengan pembakaran dalam tanur pada suhu $550^{\circ} \mathrm{C}$, dan kadar air dilakukan dengan pengeringan dalam oven pada suhu $110^{\circ} \mathrm{C}$ hingga bobot konstan. Analisis proksimat dilakukan di Laboratorium Balai Penelitian dan Pengembangan Budidaya Air Payau, Maros.

Peubah yang diamati meliputi: laju metamorfosis/ perkembangan larva, laju konsumsi alga, dan sintasan larva. Interval pengamatan perkembangan larva, laju konsumsi alga, dan sintasan larva dilakukan setiap perubahan fase larva. Sebagai data penunjang dilakukan pengamatan kualitas air setiap tiga hari sekali meliputi: suhu, salinitas, $\mathrm{pH}$, dan oksigen terlarut. Setelah larva mencapai stadia PL-1, semua larva pada masing-masing wadah dipanen dan dihitung untuk menentukan sintasannya. Data laju metamorfosis/perkembangan larva dan sintasan larva dianalisis ragam, sedangkan laju konsumsi alga dan kualitas air disajikan secara tabulasi dan grafik serta dianalisis secara deskriptif.

\section{HASIL DAN BAHASAN}

Pengamatan selama penelitian menunjukkan bahwa pemeliharaan larva udang windu sampai stadia postlarva- 1 menghasilkan sintasan tertinggi yaitu $41,48 \%$ pada aplikasi pakan alami Chaetoceros gracilis dan sintasan terendah adalah $28,02 \%$ dengan aplikasi pakan alami Chaetoceros simplex. Selanjutnya hasil analisis ragam menunjukkan bahwa sintasan larva 
dengan aplikasi pakan alami $C$. gracilis berbeda nyata $(\mathrm{P}<0,05)$ bila dibandingkan dengan sintasan larva dengan aplikasi pakan alami Chaetoceros ceratosporum $(30,37 \%)$, Chaetoceros amami $(29,26 \%$, dan C. simplex $(28,02 \%)$, namun tidak berbeda nyata $(\mathrm{P}>0,05)$ dengan sintasan larva $(35,56 \%)$ dengan aplikasi pakan alami Chaetoceros calcitrans (Tabel 3). Perbedaan sintasan yang didapatkan pada penelitian ini disebabkan oleh perbedaan kemampuan larva dalam memanfaatkan makanan alami. Sintasan larva udang windu lebih tinggi dengan pemberian $C$. gracilis karena memiliki ukuran berkisar 6-12 $\mu \mathrm{m}$, merupakan ukuran plankton yang masih dapat diterima larva udang yaitu sekitar 3-30 $\mu \mathrm{m}$ (Vey \& Fox, 1983). Selanjutnya Tzardis et al. (1993) menguraikan kandungan nutrien $C$. gracilis terdiri atas vitamin $1,6 \%$, chlorofil-a $1,04 \%$, protein $27,68 \%$, karbohidrat 23,2\%, lemak 9,27\%, EPA 5,0\%, dan DHA $0,5 \%$. Sedangkan kandungan nutrien $C$. calcitrans meliputi: protein 20,1\%, lemak 9,9\%, DHA 1,4\%, dan EPA 15,3\% (Okauchi et al., 1997). Untuk jenis C. amami, memiliki kandungan gizi yaitu: protein 33\%, karbohidrat $17 \%$, lemak $10 \%$, mineral $29 \%$, EPA $15,4 \%$, dan DHA 1,9\% (Nancy \& John. 1990). C. ceratosporum me- miliki kandungan gizi yaitu: protein 3,99\%, lemak $0,29 \%$, kadar abu $66,84 \%$, serat kasar 3,01\%, dan BETN 26,26\% (Ekawati et al., 2010). Selanjutnya hasil analisis komposisi proksimat Chaetoceros spp. dapat dilihat pada Tabel 4 .

Pada stadia awal larva, struktur dan fungsi saluran pencernaan masih sangat sederhana sehingga komposisi nutrien, ukuran, dan bentuk sel pakan alami mempengaruhi daya cerna larva. Selanjutnya pada stadia awal larva aksi mekanik dalam saluran cerna belum berkembang sehingga peranan enzim pencernaan sangat penting. Menurut Burford \& Preston (1994), bahwa pakan alami diatom berpengaruh terhadap sintasan dan pertumbuhan larva udang windu, di mana kandungan nutrien pakan yang sempurna memberikan kecenderungan sintasan larva lebih tinggi dari sintasan larva yang menggunakan pakan dengan kandungan nutrien yang tidak lengkap. Sintasan larva yang didapatkan pada penelitian ini lebih rendah dari sintasan larva hasil penelitian yang dilakukan Simon (1978) dengan mengaplikasikan pakan alami yang sama (C. gracilis) diperoleh sintasan Penaeus stylirostris dan Penaeus vannamei sampai stadia mysis

Tabel 3. Sintasan dan laju metamorfosis larva udang windu P. monodon yang diberi pakan alami Chaetoceros spp. yang berbeda selama penelitian

Table 3. Survival rate and metamorphosis stage of tiger shrimp larvae P. monodon fed with different Chaetoceros spp. during experiments

\begin{tabular}{lcc}
\hline $\begin{array}{c}\text { Perlakuan } \\
\text { Treatment }\end{array}$ & $\begin{array}{c}\text { Sintasan } \\
\text { Survival rate (\%) }\end{array}$ & $\begin{array}{c}\text { Laju metamorfosis } \\
\text { Metamorphosis stage (\%) }\end{array}$ \\
\hline C. simplex & $28.02 \pm 11.3^{\mathrm{a}}$ & $5.77 \pm 0.06^{\mathrm{a}}$ \\
C. ceratosporum & $30.37 \pm 2.8^{\mathrm{a}}$ & $5.59 \pm 0.02^{\mathrm{a}}$ \\
C. calcitrans & $35.56 \pm 1.1^{\mathrm{ab}}$ & $5.78 \pm 0.08^{\mathrm{a}}$ \\
C. amami & $29.26 \pm 6.2^{\mathrm{a}}$ & $5.53 \pm 0.11^{\mathrm{a}}$ \\
C. gracilis & $41.48 \pm 5.3^{\mathrm{b}}$ & $5.93 \pm 0.02^{\mathrm{a}}$ \\
\hline
\end{tabular}

Keterangan (Note):

Nilai dengan huruf yang sama pada kolom yang sama menunjukkan tidak berbeda nyata $(P>0,05)$ Values with the same letter in the same colomn indicate not significantly different $(P>0.05)$

Tabel 4. Komposisi proksimat Chaetoceros spp. (\% bobot kering)

Table 4. Proximate composition of Chaetoceros spp. (\% dry weight)

\begin{tabular}{|c|c|c|c|c|}
\hline \multirow{2}{*}{$\begin{array}{l}\text { Perlakuan } \\
\text { Treatment }\end{array}$} & \multicolumn{4}{|c|}{ Variabel (Variables) } \\
\hline & $\begin{array}{l}\text { Protein kasar } \\
\text { Crude protein }\end{array}$ & $\begin{array}{c}\text { Lemak kasar } \\
\text { Crude fat }\end{array}$ & $\begin{array}{l}\text { Kadar air } \\
\text { Moisture }\end{array}$ & $\begin{array}{l}\text { Abu } \\
\text { Ash }\end{array}$ \\
\hline C. simplex & 7.95 & 0.39 & 13.04 & 57.90 \\
\hline C. ceratosporum & 19.83 & tds & 14.37 & 54.32 \\
\hline C. calcitrans & 23.53 & 0.47 & 13.37 & 50.94 \\
\hline C. amami & 16.39 & tds & 11.88 & 39.68 \\
\hline C. gracilis & 18.49 & 0.42 & 11.93 & 51.28 \\
\hline
\end{tabular}

Keterangan (Note): Tds $=$ Tidak terdeteksi (Not detection) 
adalah $84,8 \%$. Sintasan larva yang berbeda disebabkan jenis larva yang digunakan berbeda dan waktu penelitian berbeda. Selama aplikasi pakan alami Chaetoceros spp. pada penelitian ini perubahan stadia larva tidak bersamaan pada kelima perlakuan, namun aplikasi $C$. gracilis perubahan stadia relatif lebih cepat satu hari dibandingkan keempat perlakuan lainnya sehingga memberikan sintasan larva lebih tinggi dibandingkan sintasan larva perlakuan lainnya. Hasil pengamatan sintasan larva udang windu mulai stadia zoea-1 sampai dengan postlarva-1 dengan aplikasi pakan alami Chaetoceros spp. yang berbeda selama penelitian disajikan pada Gambar 1 .

Salah satu faktor yang mendukung sintasan larva adalah kemampuan larva memanfaatkan pakan alami yang diberikan. Hasil pengamatan selama penelitian menunjukkan bahwa laju konsumsi alga oleh larva semakin meningkat sesuai dengan perkembangan larva udang. Pada penelitian ini, laju konsumsi alga tertinggi oleh larva pada stadia mysis-3 yaitu $C$. gracilis (34,50 x 10² sel/larva/jam) dan laju konsumsi alga terendah yaitu $C$. calcitrans (29,96 x 10² sel/larva/jam). Selanjutnya laju konsumsi alga tertinggi oleh larva stadia PL-1 adalah $C$. gracilis $\left(33,28 \times 10^{2}\right.$ sel/larva/ jam) dan terendah oleh larva yaitu $C$. simplex $(29,28 \mathrm{x}$ $\left.10^{2} \mathrm{sel} / \mathrm{larva} / \mathrm{jam}\right)$. Hasil penelitian ini mengindikasikan bahwa laju konsumsi alga yang tinggi oleh larva cenderung akan memberikan sintasan larva yang tinggi.

Jumlah pakan yang dikonsumsi oleh larva udang windu dipengaruhi oleh kepadatan, ukuran, dan pergerakan larva. Larva udang menyaring makanan menggunakan setae, selanjutnya mikroalga yang terperangkap pada setae dimasukkan ke dalam mulut oleh maksilla, dalam mekanisme ini tidak semua makanan yang terperangkap pada setae dapat dikonsumsi larva. Selanjutnya pada stadia mysis-1, kaki jalan mulai berkembang tetapi belum berfungsi secara maksimal. Efisiensi menangkap makanan tertinggi pada stadia mysis-3 dan menurun pada stadia postlarva-1. Pada penelitian ini, laju konsumsi alga tertinggi terjadi pada stadia mysis-3, oleh karena pada stadia mysis-3 gigi dan saluran pencernaan telah berkembang dengan sempurna (Gambar 2).

Laju konsumsi alga oleh larva pada stadia mysis-3 dan pada stadia postlarva-1 disajikan pada Tabel 5 . Abubakar (1991) menyatakan bahwa pada stadia mysis-3 saluran pencernaan larva telah berkembang secara sempurna dan larva telah bersifat karnivora. Pada stadia ini, makanan tertahan lebih lama dalam saluran pencernaan sehingga penyerapan lebih tinggi dibandingkan dengan stadia zoea.

\section{Laju Metamorfosis/Perkembangan Larva}

Hasil pengamatan perkembangan larva pada akhir penelitian yaitu pada stadia postlarva-1 relatif sama antara kelima aplikasi pakan alami Chaetoceros spp. berkisar 5,53-5,93 (Tabel 3). Laju metamorfosis/perkembangan larva mulai stadia Z-1 sampai dengan postlarva-1 disajikan pada Gambar 3. Pada Gambar 3 terlihat bahwa perkembangan larva pada aplikasi kelima jenis pakan alami Chaetoceros spp. relatif sama

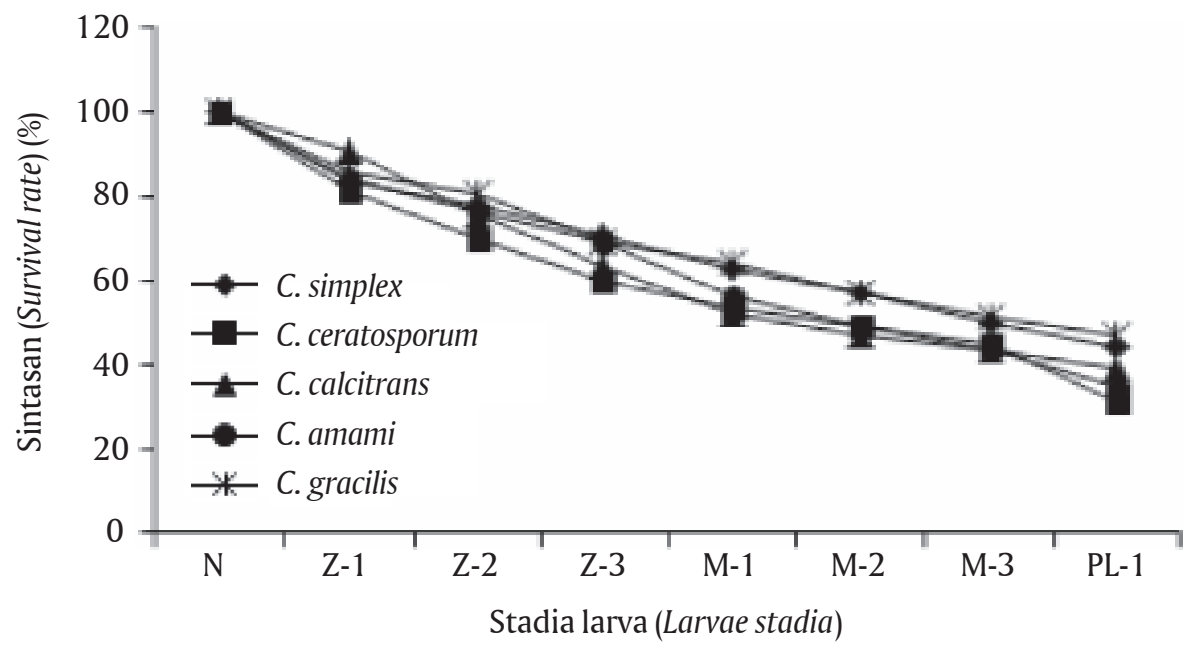

Keterangan (Note):

$\mathrm{N}=$ Naupli, Z-1 = Zoea-1, Z-2 = Zoea-2, Z-3 = Zoea-3, M-1 = Mysis-1, M-2 = Mysis-2,

M-3 = Mysis-3, PL-1 = Postlarva-1

Gambar 1. Sintasan larva udang windu P. monodon yang diberi pakan alami Chaetoceros spp. yang berbeda selama penelitian

Figure 1. Survival rate of prawn larvae P. monodon fed with different Chaetoceros spp. during the experiment 


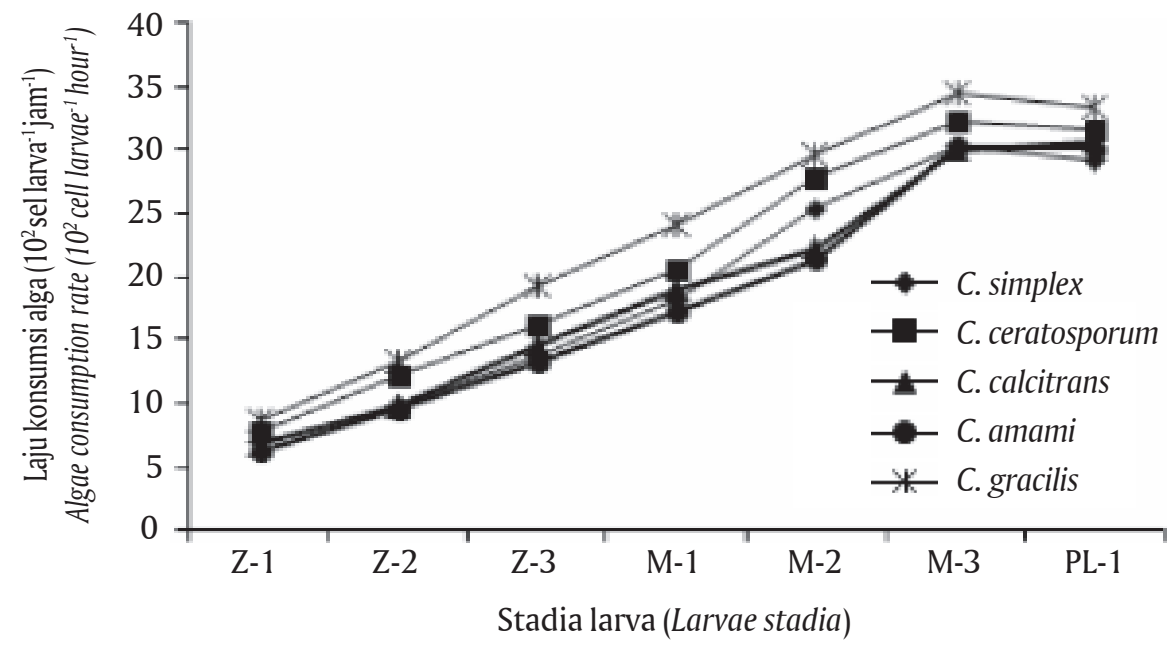

Keterangan (Note):

Z-1 = Zoea-1, Z-2 = Zoea-2, Z-3 = Zoea-3, M-1 = Mysis-1, M-2 = Mysis-2, M-3 = Mysis-3, PL-1 = Postlarva- 1

Gambar 2. Laju konsumsi alga, Chaetoceros spp. oleh larva udang windu P. monodon selama penelitian

Figure 2. Algae Chaetoceros spp consumption rate, by tiger shrimp larvae P. monodon during the experiment

Tabel 5. Laju konsumsi alga (sel/larva/jam) larva udang windu P. monodon yang diberi pakan alami Chaetoceros spp. yang berbeda selama penelitian

Table 5. Algae consumption rate (cell/larvae/hour) of prawn larvae P. monodon fed with different Chaetoceros spp. during the experiments

\begin{tabular}{lccc}
\hline $\begin{array}{c}\text { Perlakuan } \\
\text { Treatment }\end{array}$ & $\begin{array}{c}\text { Stadia zoea } \\
\text { Zoea stadia }\end{array}$ & $\begin{array}{c}\text { Stadia mysis } \\
\text { Mysis stadia }\end{array}$ & $\begin{array}{c}\text { Stadia PL-1 } \\
\text { PL-1 stadia }\end{array}$ \\
\hline C. simplex & $13.80 \times 10^{2}$ & $30.28 \times 10^{2}$ & $29.28 \times 10^{2}$ \\
C. ceratosporum & $16.09 \times 10^{2}$ & $32.25 \times 10^{2}$ & $31.58 \times 10^{2}$ \\
C. calcitrans & $14.51 \times 10^{2}$ & $29.96 \times 10^{2}$ & $30.69 \times 10^{2}$ \\
C. amami & $13.22 \times 10^{2}$ & $30.18 \times 10^{2}$ & $30.09 \times 10^{2}$ \\
C. gracilis & $19.23 \times 10^{2}$ & $34.50 \times 10^{2}$ & $33.28 \times 10^{2}$ \\
\hline
\end{tabular}

selama pengamatan. Hal ini diduga disebabkan oleh kandungan nutrisi dari masing-masing pakan alami yang diaplikasikan relatif sama oleh karena masih dalam satu kelompok Chaetoceros spp. Okauchi et al. (1997) menguraikan komposisi protein dan total lemak jenis Chaetoceros spp., antara lain: $C$. neogracilis (protein dan total lemak adalah $24,0 \%$ dan $11,8 \%$ ), $C$. calcitrans (protein dan total lemak: 20,1\% dan 9,9\%) dan Chaetoceros sp. lainnya (protein $22,3 \%$ dan total lemak $11,0 \%$ ). Demikian pula ukuran jenis plankton C. ceratosporum berkisar 5-7 $\mu \mathrm{m}$ relatif sama dengan ukuran jenis plankton $C$. gracilis berkisar 6-12 $\mu \mathrm{m}$.

Selain itu, kelima jenis Chaecoceros spp. yang diaplikasikan memiliki komposisi nutrien yang relatif sama. Chaetoceros spp. juga memiliki hubungan kekerabatan yang dekat antara kelimanya dengan nilai berkisar 93-98\% (Herlinah \& Parenrengi, 2012). Se- lanjutnya kelima jenis Chaetoceros spp. yang diaplikasikan memiliki variasi genetik yang kecil berkisar 0,0017-0,0173 (Herlinah \& Tenriulo, 2012). Pengamatan perkembangan larva udang yang diperoleh pada penelitian ini relatif sama dengan hasil penelitian Haryanti et al. (1991) yang menyatakan bahwa perkembangan larva yang diberi pakan alami $C$. ceratosporum tidak berbeda dengan perkembangan larva yang diberi pakan alami $C$. calcitrans.

Salah satu faktor yang mempengaruhi pertumbuhan larva udang adalah kualitas air. Pengamatan kualitas air selama penelitian (Tabel 6) memperlihatkan bahwa secara umum kisaran parameter tersebut masih berada pada kriteria pemeliharaan larva udang pada umumnya, termasuk udang windu sebagai hewan uji dalam penelitian ini. Kungvangkij (1988) menyatakan bahwa pada suhu $28^{\circ} \mathrm{C}$ pertumbuhan stadia 


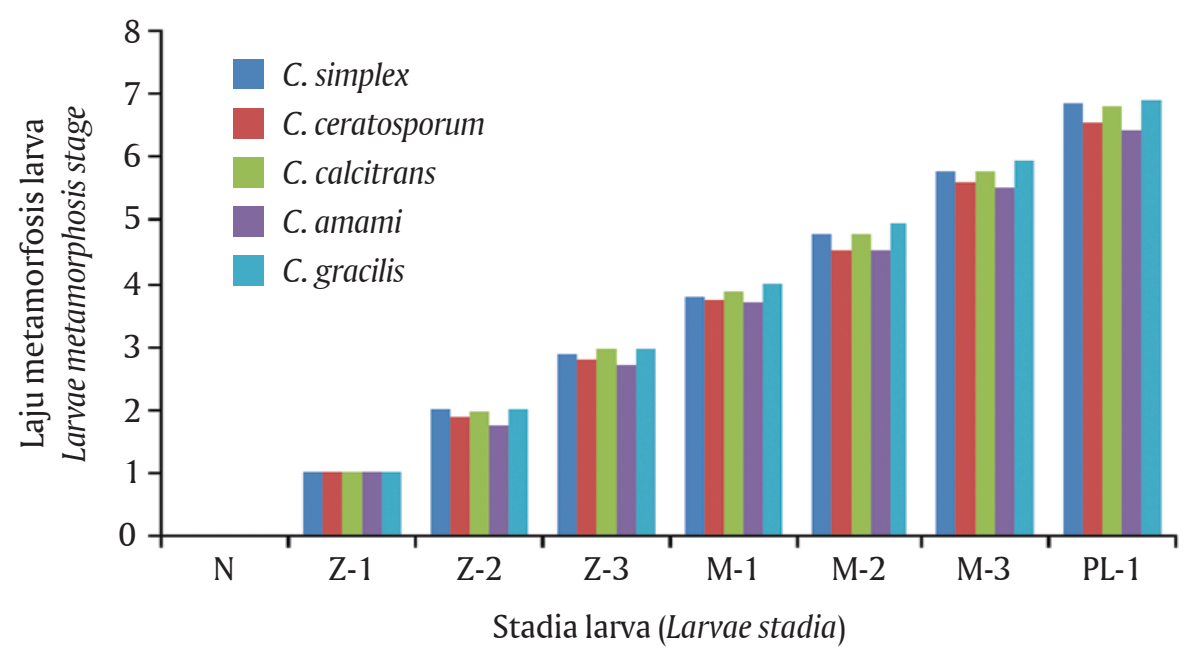

Keterangan (Note):

$\mathrm{N}=$ Naupli, Z-1 = Zoea-1, Z-2 = Zoea-2, Z-3 = Zoea-3, M-1 = Mysis-1, M-2 = Mysis-2, M-3 = Mysis-3, PL-1 = Postlarva-1

Gambar 3. Laju metamorfosis/perkembangan larva udang windu P. monodon yang diberi pakan Chaetoceros spp. selama penelitian

Figure 3. Larvae metamorphosis rate/development of shrimp prawn P. monodon fed with Chaetoceros spp during experiment

Tabel 6. Data kualitas air dalam bak pemeliharaan larva selama penelitian

Table 6. Water quality parameter in larval rearing tank during the experiment

\begin{tabular}{lcccc}
\hline $\begin{array}{c}\text { Perlakuan } \\
\text { Treatment }\end{array}$ & $\begin{array}{c}\text { Suhu } \\
\text { Temperature }\left({ }^{\circ} \mathbf{C}\right)\end{array}$ & $\mathbf{p H}$ & $\begin{array}{c}\text { Salinitas } \\
\text { Salinity }(\mathbf{p p t})\end{array}$ & $\begin{array}{c}\text { Oksigen terlarut } \\
\text { Dissolved oxygen }(\mathbf{m g} / \mathbf{L})\end{array}$ \\
\hline C. simplex & $28.83 \pm 1.09$ & $7.11 \pm 0.53$ & $29.75 \pm 0.66$ & $4.89 \pm 0.42$ \\
C. cheratosporum & $28.92 \pm 1.03$ & $7.10 \pm 0.54$ & $29.84 \pm 0.61$ & $4.70 \pm 0.45$ \\
C. calcitrans & $28.97 \pm 1.02$ & $7.11 \pm 0.55$ & $29.76 \pm 0.67$ & $4.83 \pm 0.31$ \\
C. amami & $28.99 \pm 1.01$ & $7.13 \pm 0.54$ & $29.95 \pm 0.34$ & $4.82 \pm 0.37$ \\
C. gracilis & $28.75 \pm 1.09$ & $7.01 \pm 0.55$ & $30.03 \pm 0.09$ & $4.94 \pm 0.48$ \\
\hline
\end{tabular}

zoea larva udang windu berlangsung selama enam hari, sedangkan dengan suhu $30^{\circ} \mathrm{C}$ proses metamorfosis larva berlangsung lebih singkat yaitu empat hari. Demikian pula dengan $\mathrm{pH}$ konsentrasi rendah akan menyebabkan ketidaknormalan pertumbuhan larva. Spotte (1992) menguraikan bahwa pada kisaran $\mathrm{pH}$ 6,4 dapat menurunkan laju pertumbuhan sebesar $60 \%$ dan menurunkan daya tahan tubuh larva terhadap serangan penyakit.

\section{KESIMPULAN}

Sintasan larva udang windu tertinggi diperoleh pada penggunaan pakan alami Chaetoceros gracilis, namun laju metamorfosis larva relatif sama untuk semua jenis Chaetoceros spp. yang diaplikasikan.

\section{UCAPAN TERIMA KASIH}

Ucapan terima kasih disampaikan kepada teknisi instalasi pembenihan udang windu Barru, Balai Pe- nelitian dan Pengembangan Budidaya Air Payau atas bantuannya selama pelaksanaan penelitian.

\section{DAFTAR ACUAN}

Abubakar, B. (1991). Studies on the functional morphology of the Decapod larval gut in relation to diet. Ph.D. Thesis, University College of North Wales, 400 pp.

AOAC International. (1999). Official methods of analysis. $16^{\text {th }}$ eds. Association of Official Analytical Chemists International, Gaithersberg, Maryland. USA, 1,141 pp.

Band-Schmidt, C.J., Chavez, R.P., \& Trujillo, S.H. (2008). Influence of Fitoplankton Diets on the Ingestion Rate and Egg Production of Acartia clause and A. iljeborgii (Copepoda; Calanoida) From Bahia De Lapaz, Gulf of California. Hidrobiologyca, 18, 133140.

Burford, M.A., \& Preston, N.P. (1994). Tropical Micro- 
algae, Their Potential for Rearing Prawn Larvae. The Third Asian Fisheries Forum, Manila Philippines, $36 \mathrm{pp}$.

Rahmadiani, W.D., \& Aunurohim. (2013). Bioakumulasi logam berat cadmium (Cd) oleh Chaetoceros calcitrans pada konsentrasi sublethal. Jurnal Sains dan Seni Pomits, 2(2), 202-206.

Effendie, M.I. (1979). Metode Biologi Perikanan. Yayasan Dewi Sri Bogor, Indonesia, $122 \mathrm{pp}$.

Ekawati, A.W., Nursyam, H., Widjayanto, E., \& Marsoedi. (2010). Diatomae Chaetoceros ceratosporum dalam formula pakan meningkatkan respon imun seluler udang windu (Penaeus monodon Fab). Jurnal Ilmu Kelautan, 15(3), 119-125.

Haryanti, Ismi, S., Khalik, A., \& Eda, H. (1991). Studi penggunaan tiga jenis diatom terhadap pertumbuhan dan kelangsungan hidup larva udang windu, Penaeus monodon.J. Penel. Budidaya Pantai, 7(1), 57-63.

Herlinah \& Parenrengi, A. (2012). Identifikasi spesies fitoplankton Chaetoceros spp. berdasarkan sekuen 16-S RNA, hlm pPN-09. Prosiding Seminar Nasional Tahunan IX Hasil Penelitian Perikanan dan Kelautan, Jurusan Perikanan Fakultas Pertanian UGM, Yogyakarta, $7 \mathrm{hlm}$.

Herlinah \& Tenriulo, A. (2012). Keragaman genetik fitoplankton Chaetoceros spp berdasarkan sekuen 16S-rRNA, hlm 1303-1309. Prosiding Indoaqua-Forum Inovasi Teknologi Akuakultur. Pusat Penelitian dan Pengembangan Perikanan Budidaya. Badan Penelitian dan Pengembangan Kelautan dan Perikanan, $6 \mathrm{hlm}$.

Kungvangkij, P. (1988). Shrimp hatchery Design. Operator and management. Naca Training Manual Series. Bangkok, $86 \mathrm{pp}$.

Liao, I.H., \& Lin, J.H. (1983). Larval Food For Penaeid Prawn. Handbook of Mariculture CRC Press. Florida. USA, 45 pp.

Nancy, M.C., \& John, R.K. 1990. Biology of Marine Plants. Longman, Melbourne, p. 99-127.

Okauchi, M., Toyoda, K., Imai, K., Suzuki, H., \& Nagumo, T. (1997). Identification of Chaetoceros neogracile and C. calcitrans Using DNA Polymorphism and Their Nutritive Value as Food Organisms. National Research Institute of Aquaculture, Fisheries Research Agency, Minamiise, Mie 5160193 Japan.

Renaud, S.M., Thinh, L.T., \& David, D.L. (1999). The Gross Chemical Composition and Fatty Acid Composition of 18 Species of Tropical Australian Microalgae for Possible Use in Mariculture. Aquaculture, 170, 147-159.

Sektiana, S.P. (2008). Pengembangan Medium Untuk Kultur Semi Massal Diatom Laut, Chaetoceros gracilis Schutt. Tesis. Pascasarjana. IPB Bogor, 135 pp.

Simon, C.M. (1978). The culture of diatom Chaetoceros gracilis and its use as a food for penaeid protozoa larvae. Aquaculture, 14, 105-113.

Spotte, S. (1992). Fish and Invertebrate Culture. Second Edition. Jhon Willey and Sons, New York, 530 pp.

Suantika, G., Adityawati, P., Astuti, D.I., \& Sofyan, Y. (2009). Pengaruh Perbedaan Kepadatan Awal Inokulum Terhadap Kualitas Kultur Chaetoceros gracilis (Schutt) Pada Sistem Batch. Jurnal Matematika dan Sains, 14(1), 1-8.

Sutomo. (2005). Kultur tiga jenis mikroalga (Tetraselmis sp., Chlorella sp., dan Chaetoceros gracilis) dan pengaruh kepadatan awal terhadap pertumbuhan Chaetoceros gracilis di Laboratorium. Jurnal Oseanologi dan Limnologi di Indonesia, 37, 43-58.

Tzardis, S.E., Patterson, G.W., Wikfors, G.H., Gladu, P.K., \& Harrison, D. (1993). Sterols of Chaetoceros and Skeletonema. Lipids. Aquaculture, 28, 465-467.

Vey, J.P.M., \& Fox, J.M. (1983). Hatchery techniques for Penaeid shrimp utilized by Texas A\&M. CRC Handbook of Mariculture. Crustacean Aquaculture Vol-1. Florida, 86 pp.

Villages, T., \& Kanazawa, A. (1979). Relation Between Diet and Growth Weight of Zoea and Mysis of Penaeus japonicus BATE. Aqua. Res. Phillipines, 4, 32-40. 